OPEN ACCESS

Edited by:

Robert Campbell,

The University of Utah, United States

Reviewed by:

Ciprian Tomuleasa,

Iuliu Hatieganu University of Medicine

and Pharmacy, Romania

Frederik Denorme,

The University of Utah, United States

*Correspondence:

Yong Yao

tigerfreeyy@126.com

${ }^{\dagger}$ These authors have contributed equally to this work and share first

authorship

Specialty section:

This article was submitted to

Hematology,

a section of the journal

Frontiers in Medicine

Received: 03 October 2020 Accepted: 10 November 2020 Published: 30 November 2020

Citation:

Zhang Y, Liu J, Zhu J, Zhou X Zhang K, Wang S, Ma W, Pan H,

Wang $R$, Zhu $H$ and Yao Y (2020) Case Report: Rosai-Dorfman Disease Involving Sellar Region in a Pediatric

Patient: A Case Report and

Systematic Review of Literature.

Front. Med. 7:613756

doi: 10.3389/fmed.2020.613756

\section{Case Report: Rosai-Dorfman Disease Involving Sellar Region in a Pediatric Patient: A Case Report and Systematic Review of Literature}

\author{
Yi Zhang ${ }^{1 \dagger}$, Jie Liu ${ }^{1 \dagger}$, Jianyu Zhu ${ }^{1 \dagger}$, Xiang Zhou ${ }^{2}$, Kun Zhang ${ }^{2}$, Shirui Wang ${ }^{2}$, Wenbin Ma ${ }^{1}$, \\ Hui Pan ${ }^{2}$, Renzhi Wang ${ }^{1}$, Huijuan $\mathrm{Zhu}^{2}$ and Yong Yao ${ }^{1 *}$ \\ 1 Department of Neurosurgery, Peking Union Medical College, Peking Union Medical College Hospital, Chinese Academy of \\ Medical Science, Beijing, China, ${ }^{2}$ Department of Endocrinology, Peking Union Medical College, Peking Union Medical \\ College Hospital, Chinese Academy of Medical Science, Beijing, China
}

Rosai-Dorfman disease (RDD) is an extremely rare histiocytic disorder characterized by cervical lymphadenopathy, while the involvement of sellar region is less observed. Here we report a pediatric patient who was initially suspected as sellar germinoma but later identified as RDD. We also conducted a systematic review about RDD involving sellar region. A total of only 14 cases were included and analyzed in our study in terms of clinical presentation, endocrine abnormality, radiological features, pathology, treatment, and follow up. The most common neurological manifestations of sellar RDD is diabetes insipidus and visual changes. Two typical kinds of MRI manifestations were presented in sellar RDD; one is like meningioma-like mass lesions, another showing infiltrative pattern that demonstrates hyperintense areas on T2WI. Currently, the treatment of RDD is tailored to the individual clinical circumstances. For sellar RDD, surgical treatment can be considered to completely remove or debulk the tumor.

Keywords: Rosai-Dorfman disease, sellar region, treatment strategies, MRI manifestation, clinical presentation

\section{INTRODUCTION}

Rosai-Dorfman disease was first reported in 1969 as sinus histiocytosis with massive lymphadenopathy, which was a benign and progressive lymphoproliferative disorder presenting with lymphadenopathies and polyclonal hypergammaglobulinemia $(1,2)$. RDD is more frequently seen in children and young adults than in older adults (3), while it seems not to present a explicit sex predilection (4). In addition, extranodal involvement has been reported in $43 \%$ of RDD, with the most common sites being the skin and the central nervous system $(\mathrm{CNS})(5,6)$. CNS involvement occurs in $<5 \%$ of cases with $75 \%$ occurring as intracranial and $25 \%$ as spinal lesions (5). Patients with primary CNS involvement are often free of the general symptoms mentioned above and may manifest with only neurological symptoms related to lesion location such as headache, seizure, and focal neurological deficits (7).

Typical manifestations of RDD include non-specific painless lymphadenopathy (most often cervical and less commonly retroperitoneal, mediastinal, axillary, or inguinal) accompanied by fever, an elevated erythrocyte sedimentation rate, elevated inflammatory markers, mild anemia, and weight loss $(2,6)$. Other common symptoms include subcutaneous masses, bone pain, constitutional symptoms, and abdominal pain (8). Surprisingly, extra nodal presentations were more common than nodal lesions $(4,8)$. 
TABLE 1 | Clinical summary of 14 RDD patients involved in sellar region in terms of clinical presentation and endocrine abnormality.

\begin{tabular}{|c|c|c|c|c|c|c|c|c|c|c|c|}
\hline \multirow[t]{2}{*}{ Authors and year } & \multirow[t]{2}{*}{ Ref.no } & \multirow{2}{*}{$\begin{array}{l}\text { Gender/ } \\
\text { age }\end{array}$} & \multicolumn{3}{|c|}{ Clinical presentation } & \multirow{2}{*}{$\begin{array}{l}\text { Clinical } \\
\text { course }\end{array}$} & \multicolumn{2}{|c|}{ Physical examination } & \multirow[b]{2}{*}{ Others } & \multicolumn{2}{|c|}{ Endocrine abnormality } \\
\hline & & & Symptoms & Fever & $\begin{array}{l}\text { Diabetes } \\
\text { insipidus }\end{array}$ & & $\begin{array}{l}\text { Palpable } \\
\text { lymphadenopathy } \\
\text { (location) }\end{array}$ & Visual acuity and field & & $\begin{array}{l}\text { Pre-op endocrine } \\
\text { examination }\end{array}$ & $\begin{array}{l}\text { Post-op } \\
\text { endocrine } \\
\text { examination }\end{array}$ \\
\hline $\begin{array}{l}\text { Bhattacharjee et al., } \\
1992\end{array}$ & (10) & M 78 & $\begin{array}{l}\text { Bilateral visual impairment, } \\
\text { mild headache, visual blurring }\end{array}$ & - & - & $8 \mathrm{~m}$ & & $\begin{array}{l}\text { Bitemporal hemianopia, } \\
\text { right optic atrophy, and } \\
\text { right relative afferent } \\
\text { pupillary defect }\end{array}$ & None & NA & NA \\
\hline Ng et al., 1995 & (11) & M 22 & $\begin{array}{l}\text { Polydipsia, polyuria, lack of } \\
\text { libido, decreased frequency of } \\
\text { shaving }\end{array}$ & - & + & $6 \mathrm{~m}$ & - & NA & $\begin{array}{l}\text { Obese, lack secondary } \\
\text { sexual characteristics }\end{array}$ & $\begin{array}{l}\text { Elevated prolactin, low } \\
\text { testosterone }\end{array}$ & NA \\
\hline Kelly et al., 1999 & (12) & F 45 & $\begin{array}{l}\text { Headaches, pyrexia, vomiting, } \\
\text { bilateral discharge from ears, } \\
\text { amenorrhea, weakness and } \\
\text { numbness of both legs, } \\
\text { unsteady gait, facial pain, } \\
\text { nasal obstruction, polyuria, } \\
\text { thirst }\end{array}$ & + & + & $3 \mathrm{~m}$ & - & NA & $\begin{array}{l}\text { Neck stiffness, otitis } \\
\text { externa, joint position sense } \\
\text { and vibration sense lost in } \\
\text { both legs and pin prick and } \\
\text { light touch diminish below } \\
\text { T2, increased knee and } \\
\text { ankle reflexes }\end{array}$ & $\begin{array}{l}\text { Low cotisol, prolactin, TSH, } \\
\text { LH, T4, E2, IGF-1 }\end{array}$ & H,NA \\
\hline Woodcock et al., 1999 & (13) & F 15 & $\begin{array}{l}\text { Amenorrhea, headache, } \\
\text { blurred vision }\end{array}$ & - & - & $7 y$ & - & Blurred vision & Normal & NA & NA \\
\hline Wan et al., 2008 & (14) & M 43 & $\begin{array}{l}\text { Visual blurring of the left eye, } \\
\text { headache }\end{array}$ & - & - & $1 \mathrm{~m}$ & - & $\begin{array}{l}\text { Vision impairment of the lef } \\
\text { eye and bilateral temporal } \\
\text { visual field defect }\end{array}$ & & NA & NA \\
\hline Rotondo et al., 2010 & (15) & F 63 & $\begin{array}{l}\text { Ataxia, diarrhea, weight loss, } \\
\text { abdominal pain }\end{array}$ & - & - & $6 \mathrm{w}$ & - & NA & NA & $\begin{array}{l}\text { Low cortisol, thyroxine, } \\
\text { gomadotrophins }\end{array}$ & NA \\
\hline Gupta et al., 2011 & (16) & M 14 & Loss of vision in the left eye & - & - & $1 y$ & - & Loss of vision in the left eye & eNA & $\begin{array}{l}\text { Elevated T4, prolactin and } \\
\text { cortisol }\end{array}$ & NA \\
\hline Wang et al., 2011 & (17) & F10 & Polydipsia, polyuria & - & + & $1 \mathrm{y}$ & - & Normal & $\begin{array}{l}\text { Length and weight were } \\
\text { under } 3.97-\mathrm{ft}(121 \mathrm{~cm}) \text { and } \\
22-\mathrm{kg} \text {. Her hands and feet } \\
\text { were smaller than normal for } \\
\text { her age, rough skin }\end{array}$ & $\begin{array}{l}\text { Low cortisol, thyroxine, } \\
\text { growth hormone, and } \\
\text { gonadotrophins }\end{array}$ & NA \\
\hline Wang et al., 2011 & (17) & M 27 & $\begin{array}{l}\text { Polydipsia, polyuria, } \\
\text { headache, visual impairment, } \\
\text { weakness, decreased libido }\end{array}$ & - & + & $1 \mathrm{y}$ & - & $\begin{array}{l}\text { A reduction of visual acuity, } \\
\text { bitemporal hemianopia }\end{array}$ & & NA & $\begin{array}{l}\text { subnormal growth } \\
\text { hormone, } \\
\text { gonadotropin, and } \\
\text { cortisol }\end{array}$ \\
\hline Cangelosi et al., 2011 & (18) & F 50 & NA & - & NA & NA & - & NA & $\begin{array}{l}\text { Multiple cutaneous papules, } \\
\text { measuring up to } 0.5 \mathrm{~cm} \text {, on } \\
\text { her bilateral axilla and medial } \\
\text { thighs, just below her groin }\end{array}$ & & NA \\
\hline $\begin{array}{l}\text { Chandrashekhara } \\
\text { et al., } 2011\end{array}$ & (19) & M 30 & $\begin{array}{l}\text { Headache, vomiting, } \\
\text { diminished vision }\end{array}$ & - & - & $2 y$ & cervical & Diminished vision & $\begin{array}{l}\text { Multiple cervical } \\
\text { lymphadenopathies, } \\
\text { enlargement of } \\
\text { submandibular glands }\end{array}$ & NA & NA \\
\hline Sasidharan et al., 2020 & (20) & F 32 & $\begin{array}{l}\text { Progressive weakness of the } \\
\text { right arm, headache, } \\
\text { diminution in bilateral eyes }\end{array}$ & - & - & $2 y$ & neck nodes & Diminution in bilateral eyes & NA & NA & NA \\
\hline Sasidharan et al., 2020 & (20) & M 29 & $\begin{array}{l}\text { Progressive reduction of vision } \\
\text { in the left eye }\end{array}$ & NA & NA & NA & - & $\begin{array}{l}\text { Progressive reduction of } \\
\text { vision in the left eye }\end{array}$ & NA & NA & NA \\
\hline Our case & & M 10 & Polyuria and polydipsia & - & + & $2 y$ & - & - & $\begin{array}{l}\text { Chest discomfort, fatigue, } \\
\text { hypohidrosis, hot flush of } \\
\text { palms, and being afraid of } \\
\text { heat }\end{array}$ & $\begin{array}{l}\text { Low levels of } \mathrm{LH}, \mathrm{T} \text { and } \\
\text { slightly high level of PRL }\end{array}$ & - \\
\hline
\end{tabular}


TABLE 2 | Clinical summary of 14 RDD patients involved in sellar region in terms of radiological features, pathology, treatment, and follow up.

\begin{tabular}{|c|c|c|c|c|c|c|c|c|c|c|c|c|c|c|c|c|}
\hline \multirow{2}{*}{$\begin{array}{l}\text { Authors and } \\
\text { year }\end{array}$} & \multirow[t]{2}{*}{ Ref.no } & \multicolumn{4}{|c|}{ Blood workup } & \multicolumn{5}{|c|}{ Radiological features } & \multicolumn{3}{|c|}{ Pathology } & \multirow{2}{*}{$\begin{array}{l}\text { Solitary } \\
\text { lesion or } \\
\text { multifocal } \\
\text { lesion (detail) } \\
\text { n }\end{array}$} & \multirow{2}{*}{$\begin{array}{l}\text { Treatment } \\
\text { l) }\end{array}$} & \multirow[t]{2}{*}{ Follow up } \\
\hline & & $\begin{array}{l}\text { Elevated } \\
\text { neutrophile } \\
\text { granulocyte }\end{array}$ & ESR & hyperglobulinemia & Anemia & $\begin{array}{l}\text { Max } \\
\text { mass } \\
\text { size } \\
(\mathrm{cm})\end{array}$ & $\begin{array}{l}\text { MRI T1WI } \\
\text { (isointense } \\
\text { hypo- } \\
\text { hyper-) }\end{array}$ & $\begin{array}{l}\text { MRI T2WI } \\
\text { (isointense } \\
\text { hypo- } \\
\text { hyper-) }\end{array}$ & $\begin{array}{l}\text { Contrast } \\
\text { enhancement } \\
\text { (heterogeneous } \\
\text { homo-) }\end{array}$ & S100 & CD1a & CD68 & 8 Vimentin & & & \\
\hline $\begin{array}{l}\text { Bhattacharjee } \\
\text { et al., } 1992\end{array}$ & (10) & NA & Normal & NA & - & - & - & - & - & + & NA & NA & NA & Solitary lesion & Surgery & $1 \mathrm{y}$ alive \\
\hline Ng et al., 1995 & (11) & NA & NA & NA & NA & $\begin{array}{l}1.2 \mathrm{~cm} \text { ir } \\
\text { diameter }\end{array}$ & $\begin{array}{l}\text { in NA } \\
\text { er }\end{array}$ & NA & Heterogeneous & NA & NA & NA & NA & Solitary lesion & Surgery & NA \\
\hline Kelly et al., 1999 & (12) & NA & 55 & NA & NA & $\begin{array}{l}2 \mathrm{~cm} \text { in } \\
\text { diameter }\end{array}$ & NA & NA & Heterogeneous & + & NA & NA & NA & $\begin{array}{l}\text { Multifocal } \\
\text { lesion }\end{array}$ & Surgery & 3 y alive \\
\hline $\begin{array}{l}\text { Woodcock et al., } \\
1999\end{array}$ & (13) & NA & NA & NA & NA & NA & Isointense & Isointense & Heterogeneous & + & NA & NA & NA & Solitary lesion & Medication & $\begin{array}{l}9 \mathrm{~m} \text { slight interval } \\
\text { increase in the } \\
\text { size of the lesion }\end{array}$ \\
\hline Wan et al., 2008 & (14) & Normal & Normal & - & - & $\begin{array}{l}3 \times 3 \times \\
2.5\end{array}$ & Isointense & Isointense & Heterogeneous & + & - & + & NA & Solitary lesion & Surgery & $3 \mathrm{~m}$ alive \\
\hline $\begin{array}{l}\text { Rotondo et al., } \\
2010\end{array}$ & (15) & NA & NA & NA & 99-mild & $\begin{array}{l}1.7 \times 0 . \\
\times 0.2\end{array}$ & $.7 N A$ & NA & NA & NA & NA & + & NA & $\begin{array}{l}\text { Multifocal } \\
\text { lesion }\end{array}$ & Surgery & $\begin{array}{l}\text { Perioperative } \\
\text { period died }\end{array}$ \\
\hline $\begin{array}{l}\text { Gupta et al., } \\
2011\end{array}$ & (16) & Normal & Elevated & $d-$ & - & NA & NA & Hypointense & Homogeneous & + & NA & NA & NA & Solitary lesion & Surgery & NA \\
\hline $\begin{array}{l}\text { Wang et al., } \\
2011\end{array}$ & (17) & Normal & Normal & - & - & NA & Hyperintense & NA & Heterogeneous & + & NA & + & NA & $\begin{array}{l}\text { Multifocal } \\
\text { lesion }\end{array}$ & Surgery & 6 y alive \\
\hline $\begin{array}{l}\text { Wang et al., } \\
2011\end{array}$ & (17) & NA & elevated & NA & NA & NA & Isointense & Isointense & Heterogeneous & + & - & + & NA & $\begin{array}{l}\text { Multifocal } \\
\text { lesion }\end{array}$ & Surgery & $5 y$ alive \\
\hline $\begin{array}{l}\text { Cangelosi et al., } \\
2011\end{array}$ & (18) & NA & NA & NA & NA & NA & NA & NA & NA & + & - & + & NA & $\begin{array}{l}\text { Multifocal } \\
\text { lesion }\end{array}$ & Surgery & NA \\
\hline $\begin{array}{l}\text { Chandrashekhara } \\
\text { et al., } 2011\end{array}$ & (19) & NA & NA & NA & NA & NA & Isointense & Isointense & Heterogeneous & + & - & + & NA & Solitary lesion & Surgery & NA \\
\hline $\begin{array}{l}\text { Sasidharan } \\
\text { et al., } 2020\end{array}$ & (20) & NA & NA & NA & NA & NA & NA & NA & Homogeneous & + & - & NA & NA & $\begin{array}{l}\text { Multifocal } \\
\text { lesion }\end{array}$ & $\begin{array}{l}\text { Surgery+ } \\
\text { Radiotherapy }\end{array}$ & $\begin{array}{l}\text { Free of disease } \\
\text { progression } 35 \\
\text { months after } \\
\text { therapy }\end{array}$ \\
\hline $\begin{array}{l}\text { Sasidharan } \\
\text { et al., } 2020\end{array}$ & (20) & NA & NA & NA & NA & NA & NA & NA & Homogeneous & + & - & NA & NA & Solitary lesion & $\begin{array}{l}\text { Surgery+ } \\
\text { Radiotherapy }\end{array}$ & $\begin{array}{l}\text { Alive with } \\
\text { improvement in } \\
\text { his vision after } \\
25 \text { months of } \\
\text { therapy }\end{array}$ \\
\hline Our case & & $\begin{array}{l}\text { A higher } \\
\text { proportion of } \\
\text { lymphocyte } \\
\text { and a lower } \\
\text { proportion of } \\
\text { neutrocyte }\end{array}$ & Normal & - & - & NA & - & - & Homogenous & + & $\begin{array}{l}\text { Sparesly } \\
\text { positive }\end{array}$ & $y+$ & NA & Solitary lesion & $\begin{array}{l}\text { Surgery+ } \\
\text { Chemotherapy }\end{array}$ & $\begin{array}{l}\text { Symptoms of } \\
\text { polyuria and } \\
\text { polydipsia } \\
\text { persisted } 2 \text { ys } \\
\text { later }\end{array}$ \\
\hline
\end{tabular}



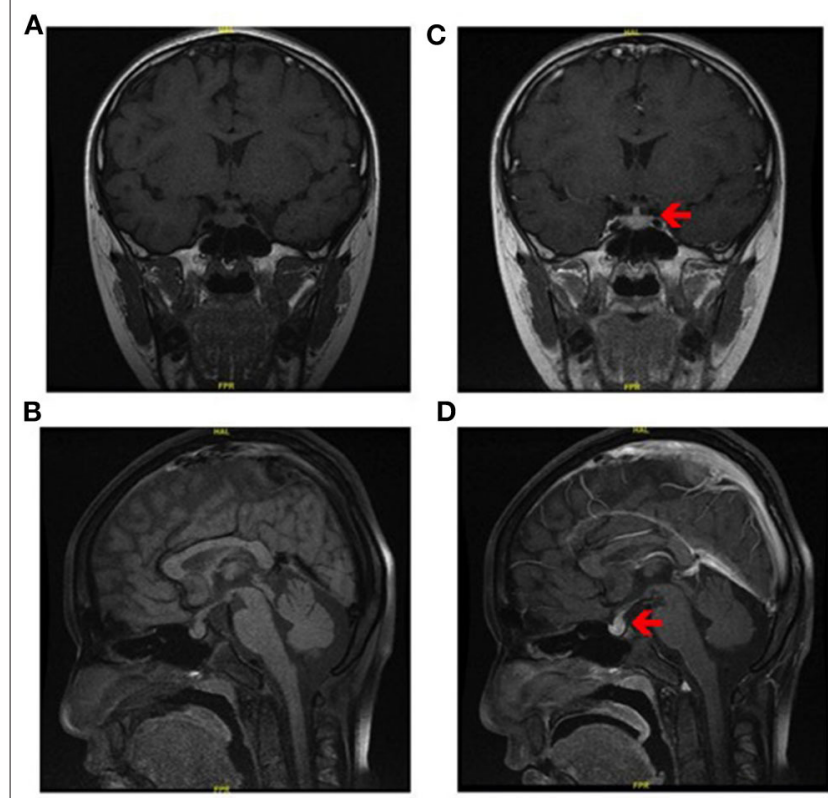

FIGURE 1 | MRI characteristics of Rosai-Dorfman disease involving sellar region. (A) Coronal and (B) sagittal T1-weighted magnetic resonance images. (C) coronal and (D) sagittal contrast-enhanced magnetic resonance images reveal thickened pituitary stalk with obvious homogenous enhancement (red arrow).

Up to $70 \%$ of patients show no associated lymphadenopathy. The most common site of CNS involvement is the dura as well as the parasellar, cavernous sinus, petroclival, and parafalcine regions-the cerebellopontine angle and posterior fossa (9), but the pituitary involvement of RDD is extremely rare. Although some authors reported some cases, none of them have summarized these comprehensive data in a systematic way. Here, we report a case of pediatric RDD with primary pituitary involvement. And a systematic review of 14 cases of symptomatic sellar RDD is conducted (Tables 1, 2).

\section{CASE PRESENTATION}

\section{History and Examination}

A 10-year-old boy presented to our clinic in September 2018 with polyuria and polydipsia without obvious precipitating factors for 2 months and chest discomfort for over half of a month. His urine output was about $8,000 \mathrm{ml}$ per day. Urine and plasma osmotic pressure were 88 and $310 \mathrm{mOsm} / \mathrm{kgH} 2 \mathrm{O}$, respectively. Water deprivation test was positive. The patient also complained of fatigue, hypohidrosis, hot flush of palms and being afraid of heat. His previous history included cerebral hemorrhage and concussion due to traffic accident in the year of 2014. No sequelae were left.

Clinical examination was normal except for slight subxiphoid tenderness. Neither lymphadenopathy nor hepatosplenomegaly was observed. Contrast-enhanced brain MRI showed that the pituitary stalk was thickened with obvious homogenous enhancement and the high signal of posterior pituitary was disappeared in T1-weighted images (Figure 1). Examination of CSF revealed normal $\beta$-hCG (0.69 IU/L, normal range: 0-5 IU/L) and AFP $(<0.605 \mathrm{ng} / \mathrm{ml})$, normal glycorrhachia, protein, and chlorine levels, normal cell count. Laboratory test showed a higher proportion of lymphocyte $(41.4 \%$, normal range: $20-40 \%)$ and a lower proportion of neutrocyte (49.6\%, normal range: 50-75\%). Endocrine studies revealed low levels of $\mathrm{LH}$ (0.98 IU/L, normal range: 1.24-8.62 IU/L), T $(0.14 \mathrm{ng} / \mathrm{ml}$, normal range: $1.75-7.81 \mathrm{ng} / \mathrm{ml})$, and slightly high level of PRL (16.54 ng/ml, normal range: $2.64-13.13 \mathrm{ng} / \mathrm{ml})$. Plasma AFP and $\beta$-hCG was normal $(3.7 \mathrm{ng} / \mathrm{ml}$ and 0.79 $\mathrm{IU} / \mathrm{L}$, respectively).

Considering his medical history, radiological test, examination of CSF and plasma, a diagnosis of central diabetes insipidus was initiated and possibly the germinoma, which required surgical biopsy to confirm it.

\section{Surgical Biopsy and Histological Findings}

Two days after admission, the patient underwent surgical biopsy using endoscopic transsphenoidal approach. The mass tissue was in the posterior sella with soft texture, gray-white color, and insufficient blood supply. H-E staining of specimen revealed the large-size histiocyte with the typically foamy eosinophilic cytoplasm. Immunohistochemical study revealed the histiocytes were positive for CD68, S-100, and negative for Langerin. The index of CD1a and CD21 were sparsely positive in the tissue. Only a few cells expressed CD3 and CD20. Cell proliferation index Ki-67 was 5\%. The diagnosis of Rosai-Dorfman disease was therefore yielded (Figure 2).

\section{Postoperative Course}

Since histological diagnosis of Rosai-Dorfman disease was confirmed, FDG-PET/CT was performed to explore whether there were systemic lesions. PET/CT revealed abnormal hypermetabolic foci in the pituitary which is considered as residual RDD lesion. Bony changes and hypermetabolic foci were also seen in the right sternal end of clavicle, right transverse process of T10, left acetabulum and right femoral head. No abnormal lesions were found in head, neck, thorax, abdomen, and pelvis (Figure 3).

The patient then started oral minirin treatment $(0.25 \mathrm{mg}$ per day) and received oral medication of chemotherapy (mercaptopurine, dose dependent on blood workup) with intermittent corticoid treatment. At the last follow up in August 2020 , the patient persisted symptoms of polyuria and polydipsia and continued chemotherapy and minirin treatment. Regular MRI of every 3 months revealed no progression.

\section{DISCUSSION}

RDD is a benign, self-limiting, and progressive lymphoproliferative disorder of unknown etiology and pathogenesis with good outcome $(2,17)$. It was originally described by Destombes in 1965 (21) and characterized as a distinct clinicopathological disorder in 1969 by Rosai and Dorfman (1). Recently, RDD has been recently classified as part 

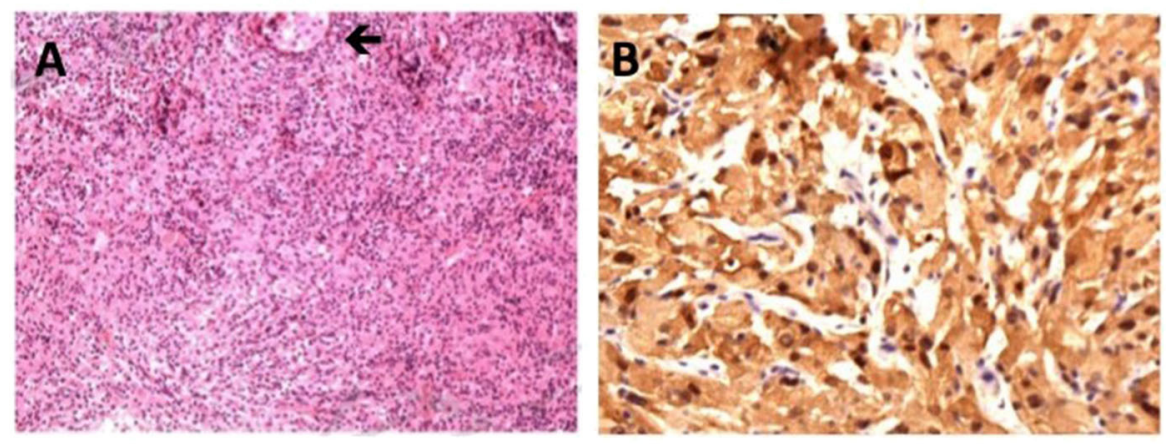

FIGURE 2 | Histological features of Rosai-Dorfman disease involving sellar region. (A) H-E staining of specimen reveals the large-size histiocyte with the typically foamy eosinophilic cytoplasm, original magnification $\times 40$ (black arrow). (B) Positive immunohistochemical staining for S-100, original magnification $\times 100$.

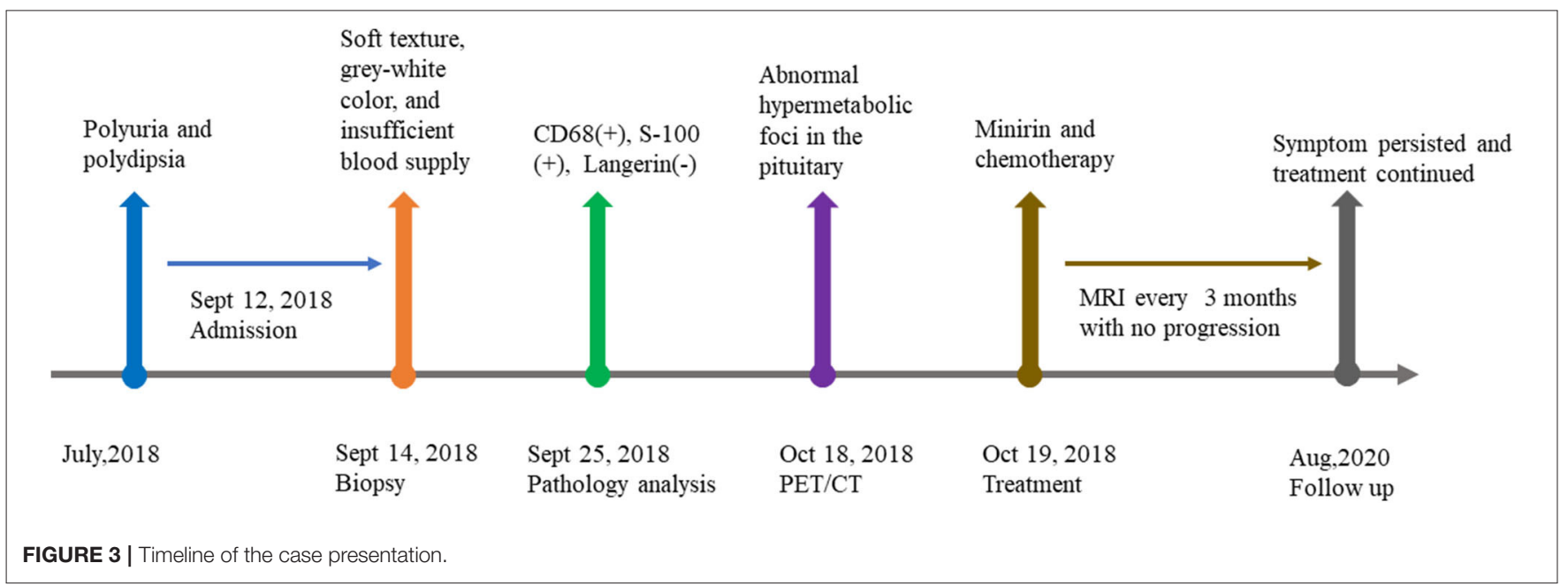

of the "R group" of histiocytoses by the Histiocyte Society in 2016 (22). The prevalence is about 1:200,000 and an estimated 100 new cases/year in the United States. It is more frequently seen in children and young adults (mean age 20.6 years), although it has been reported up to age 74 (5).

We conducted the literature review using PubMed database. Key words of "Rosai-Dorfman disease," "Rosai-Dorfman disease" with "central nervous system" and "Sinus histiocytosis with massive lymphadenopathy" were used to select for adequate papers up to August 2020 in which the diagnosis of RDD was confirmed histologically. Cases with sellar involvement were included. Only English studies are considered and those articles lacking full text or important information were also filtered out. In addition, we also reviewed references of relevant studies. A total of 14 cases (including our case) were reviewed in terms of clinical presentation, endocrine abnormality, radiological features, pathology, treatment, and follow up.

It has been suggested that dysfunction of the immune system, or an autoimmune process may be the cause of this disease (23). The clinical symptoms vary as a result of the involvement of different organs or systems. The most common neurological manifestations of sellar RDD is diabetes insipidus and visual changes. Others include high cranial pressure, neuropsychiatric manifestations, and cranial nerve paresis, et al. In our analysis, visual disturbance presents in $50 \%$ and diabetes insipidus in $42 \%$, followed by headache in $33 \%$. Visual disturbance includes blurred vision, visual field defects and diplopia. Two typical kinds of MRI manifestations in intracranial RDD have been described in our study; one is like meningiomalike mass lesions, another showing infiltrative pattern that demonstrates hyperintense areas on T2-weighted imaging. Heterogeneous contrast enhancement is usually present. These are in agreement with our findings. Fifty-four percentage of the involved lesions are heterogeneously enhanced after Gd injection.

Currently, there is no clear consensus on the treatment strategies. For sellar RDD, surgical treatment is primarily considered and the aim of it is to completely remove or debulk the tumor. Clinical course is determined by the extent and distribution of the lesion. Previous studies showed that the presence of widespread systemic disease appeared to be an ominous prognostic factor $(2,24)$. In our analysis, $92 \%$ of patients underwent operations, including craniotomy and endoscopic 
surgery. Six patients with sellar RDD achieved complete or partial remission.

Some limitations also should be noted in this study. Firstly, selection bias may be present in this study because severe or unusual cases were more easily to be published. Secondly, Neyman bias gives an inaccurate data analysis. The undiagnosed dead were not included in this study probably because of poor treatment or not performing histological analysis. Thirdly, the relatively smaller number of cases in some studies limited the power to generate statistically significant evidence of disease associations.

In conclusion, we reported a case of sellar RDD and described the largest corpus of case review of RDD with primary sellar involvement. The underlying pathogenesis and origin of sellar RDD are discussed in this article via the analysis of demographic characteristics, clinical presentations, laboratory results, radiological features, pathohistology findings, treatment, and outcomes. We believe the data summarized here will help alert us to this condition and inspire more treatment strategies in the future.

\section{DATA AVAILABILITY STATEMENT}

The original contributions presented in the study are included in the article/supplementary materials, further inquiries can be directed to the corresponding author.

\section{REFERENCES}

1. Rosai J, Dorfman RF. Sinus histiocytosis with massive lymphadenopathy. A newly recognized benign clinicopathological entity. Arch Pathol. (1969) 87:63-70.

2. Zaveri J, La Q, Yarmish G, Neuman J. More than just Langerhans cell histiocytosis: a radiologic review of histiocytic disorders. Radiographics. (2014) 34:2008-24. doi: 10.1148/rg.347130132

3. Sathyanarayanan V, Issa A, Pinto R, Fayad LE, Loghavi S, Hagemeister F, et al. Rosai-Dorfman disease: the MD Anderson Cancer Center Experience. Clin Lymphoma Myeloma Leuk. (2019) 19:709-14. doi: 10.1016/j.clml.2019. 06.013

4. Elshikh M, Schellingerhout D, Rayan J, Taher A, Elsayes AK, Mujtaba $\mathrm{B}$, et al. Disease characteristics, radiologic patterns, comorbid diseases, and ethnic differences in 32 patients with Rosai-Dorfman disease. J Comput Assist Tomogr. (2020) 44:450-61. doi: 10.1097/RCT.00000000000 00983

5. Abla O, Jacobsen E, Picarsic J, Krenova Z, Jaffe R, Emile JF, et al. Consensus recommendations for the diagnosis and clinical management of Rosai-Dorfman-Destombes disease. Blood. (2018) 131:2877-90. doi: 10.1182/blood-2018-03-839753

6. Dalia S, Sagatys E, Sokol L, Kubal T. Rosai-Dorfman disease: tumor biology, clinical features, pathology, and treatment. Cancer Control. (2014) 21:3227. doi: $10.1177 / 107327481402100408$

7. Adeleye AO, Amir G, Fraifeld S, Shoshan Y, Umansky F, Spektor S. Diagnosis and management of Rosai-Dorfman disease involving the central nervous system. Neurol Res. (2010) 32:572-8. doi: 10.1179/016164109X12608733393836

8. Goyal G, Ravindran A, Young JR, Shah MV, Bennani NN, Patnaik $\mathrm{MM}$, et al. Clinicopathological features, treatment approaches, and outcomes in Rosai-Dorfman disease. Haematologica. (2020) 105:348-57. doi: 10.3324/haematol.2019.219626

9. Drake-Pérez M, Smirniotopoulos JG. Extraparenchymal lesions in adults. Neuroimaging Clin N Am. (2016) 26:621-46. doi: 10.1016/j.nic.2016.06.009

\section{ETHICS STATEMENT}

The studies involving human participants were reviewed and approved by PUMCH Institutional Review Board. The patients/participants provided their written informed consent to participate in this study. Written informed consent was obtained from the individual(s) for the publication of any potentially identifiable images or data included in this article.

\section{AUTHOR CONTRIBUTIONS}

YY, RW, and YZ: conception and design. HP, WM, and YZ: development of methodology. YZ, JL, JZ, XZ, KZ, and SW: acquisition and analysis of data. YZ, JL, and JZ: writing, review, and revision of manuscript. HZ and HP: technical and material support. YY, RW, and HZ: study supervision. All authors have read and approved the manuscript. All authors contributed to the article and approved the submitted version.

\section{FUNDING}

This study was supported by Chinese Academy of Medical Sciences Innovation Fund for Medical Sciences (No. 2016-I2M1-002) from YY and Youth Science Foundation of Peking Union Medical College Hospital (No. pumch201911867) from YZ.

10. Bhattacharjee MB, Wroe SJ, Harding BN, Powell M. Sinus histiocytosis with massive lymphadenopathy-isolated suprasellar involvement. J Neurol Neurosurg Psychiatry. (1992) 55:156-8. doi: 10.1136/jnnp.55.2.156

11. Ng HK, Poon WS. Sinus histiocytosis with massive lymphadenopathy localized to the sella. Br J Neurosurg. (1995) 9:551-5. doi: 10.1080/02688699550041223

12. Kelly WF, Bradey N, Scoones D. Rosai-Dorfman disease presenting as a pituitary tumour. Clin Endocrinol. (1999) 50:133-7. doi: 10.1046/j.1365-2265.1999.00461.x

13. Woodcock RJ Jr, Mandell JW, Lipper MH. Sinus histiocytosis (Rosai-Dorfman disease) of the suprasellar region: MR imaging findings-a case report. Radiology. (1999) 213:808-10. doi: 10.1148/radiology.213.3.r99dc30808

14. Wan S, Teng X, Zhan R, Yu J, Gu J, Zhang K. Isolated intracranial Rosai-Dorfman disease mimicking suprasellar meningioma: case report with review of the literature. J Int Med Res. (2008) 36:1134-9. doi: 10.1177/147323000803600535

15. Rotondo F, Munoz DG, Hegele RG, Gray B, Khatun N, Bonert M, et al. RosaiDorfman disease involving the neurohypophysis. Pituitary. (2010) 13:2569. doi: 10.1007/s11102-010-0228-5

16. Gupta K, Bagdi N, Sunitha P, Ghosal N. Isolated intracranial Rosai-Dorfman disease mimicking meningioma in a child: a case report and review of the literature. Br J Radiol. (2011) 84:e138-41. doi: 10.1259/bjr/15772106

17. Wang F, Qiao G, Lou X, Song X, Chen W. Intracranial recurrences of RosaiDorfman disease in the sellar region: two illustrative cases. Acta Neurochir. (2011) 153:859-67. doi: 10.1007/s00701-010-0895-z

18. Cangelosi JJ, Prieto VG, Ivan D. Cutaneous Rosai-Dorfman disease with increased number of eosinophils: coincidence or histologic variant? Arch Pathol Lab Med. (2011) 135:1597-600. doi: 10.5858/arpa.2010-0554-CR

19. Chandrashekhara SH, Manjunatha YC, Muzumder S, Bahl A, Das P, Suri V, et al. Multicentric sinus histicytosis (Rosai-Dorfman Disease): Computed tomography, magnetic resonance imaging findings. Indian J Med Paediatr Oncol. (2011) 32:174-6. doi: 10.4103/0971-5851.92826

20. Sasidharan A, Verma A, Epari S, Gupta T, Laskar S, Khanna N, et al. Symptomatic intracranial Rosai-Dorfman disease in the suprasellar region 
treated with conformal radiotherapy - a report of two cases and literature review. Neurol India. (2020) 68:489-92. doi: 10.4103/0028-3886.284371

21. Destombes P. Adenitis with lipid excess, in children or young adults, seen in the Antilles and in Mali. (4 cases). Bull Soc Pathol Exot Filiales. (1965) 58:1169-75.

22. Emile JF, Abla O, Fraitag S, Horne A, Haroche J, Donadieu J, et al. Revised classification of histiocytoses and neoplasms of the macrophage-dendritic cell lineages. Blood. (2016) 127:2672-81. doi: 10.1182/blood-2016-01690636

23. Bruce-Brand C, Schneider JW, Schubert P. Rosai-Dorfman disease: an overview. J Clin Pathol. (2020) 73:697-705. doi: 10.1136/jclinpath-2020-206733. [Epub ahead of print].

24. Haroche J, Abla O. Uncommon histiocytic disorders: Rosai-Dorfman, juvenile xanthogranuloma, and Erdheim-Chester disease. Hematol Am Soc
Hematol Educ Program. (2015) 2015:571-8. doi: 10.1182/asheducation2015.1.571

Conflict of Interest: The authors declare that the research was conducted in the absence of any commercial or financial relationships that could be construed as a potential conflict of interest.

Copyright (๑ 2020 Zhang, Liu, Zhu, Zhou, Zhang, Wang, Ma, Pan, Wang, Zhu and Yao. This is an open-access article distributed under the terms of the Creative Commons Attribution License (CC BY). The use, distribution or reproduction in other forums is permitted, provided the original author(s) and the copyright owner(s) are credited and that the original publication in this journal is cited, in accordance with accepted academic practice. No use, distribution or reproduction is permitted which does not comply with these terms. 